\title{
РОЛЬ СУДЕБНОГО ШТРАФА В РАЗВИТИИ НРАВСТВЕННЫХ НАЧАЛ УГОЛОВНОГО СУДОПРОИЗВОДСТВА
}

\section{ROLE OF JUDICIAL PENALTY \\ IN DEVELOPMENT OF MORAL INITIATION OF CRIMINAL PROCEEDINGS}

A. Soloviev

Summary. The purpose of this article is to identify patterns that contribute to the development of the moral principles of Russian criminal justice by strengthening the social component of the procedural institution of termination of criminal prosecution with the appointment of a criminal law measure in the form of a judicial fine.

Method: the method of analysis and the formal legal method were used.

Result: the author's conclusions: 1) about the close relationship of moral values and domestic criminal proceedings; 2) about the high importance of the institution of a judicial fine for the development and strengthening of the moral principles of domestic criminal proceedings; 3) about the importance of making public apologies to ensure the fairness of a court decision on the termination of criminal prosecution with the appointment of a judicial fine.

The scientific novelty and value of the work lies in a deeper understanding by the author of the relationship between the state and society in the framework of criminal procedural activities, as well as the moral principles and the educational and preventive function of criminal proceedings, the effectiveness of which can be increased by giving the procedure of public apologies the status of a mandatory condition for the termination of criminal prosecution with the appointment of a court fine.

Keywords: apologies, judicial fine, education, compensation for harm, morality, morality, guilty.
$\mathbf{H}$ и для кого не секрет, что формирование правового государства, неразрывно связано с созданием высокоорганизованного общества. В таком обществе, помимо соблюдения закона, большое значение уделяется нравственным качествам человека. Власть в государстве наделена социальной функцией, выражающейся в обеспечении целостности и упорядочении различных интересов и отношений между людьми, что определяет ее социальное содержание и неразрывную связь с обществом.
Соловьев Александр Георгиевич

Адъюнкт, Санкт-Петербургский университет МВД

России, г. Санкт-Петербург solovevag2507@gmail.com

Аннотация. Целью данной статьи является выявление закономерностей, способствующих развитию нравственных начал российского уголовного судопроизводства с помощью усиления социальной составляющей процессуального института прекращения уголовного преследования с назначением меры уголовно-правового характера в виде судебного штрафа. Метод: использовались метод анализа и формально-юридический метод. Результат: выводы автора: 1) 0 тесной взаимосвязи морально-нравственных ценностей и отечественного уголовного судопроизводства; 2) 0 высокой значимости института судебного штрафа для развития и укрепления нравственных начал отечественного уголовного судопроизводства; 3) о значении принесения публичных извинений для обеспечения справедливости судебного решения о прекращении уголовного преследования с назначением судебного штрафа. Научная новизна и ценность работы заключается в более глубоком осмыслении автором связи государства с обществом в рамках уголовно- процессуальной деятельности, а также нравственных начал и воспитательно-профилактической функции уголовного судопроизводства, эффективность реализации которой может быть повышена с помощью придания процедуре принесения публичных извинений статуса обязательного условия для прекращения уголовного преследования с назначением судебного штрафа.

Ключевые слова: извинения, судебный штраф, воспитание, заглаживание вреда, нравственность, мораль, виновный. 
ко эффективнее укреплять соблюдение законности и правопорядка, но и способствовать формированию общепринятых морально-нравственных ценностей у лиц, совершивших уголовные преступления.

Воспитание в человеке высоких нравственных качеств, как нам кажется, может быть наиболее эффективным исключительно в случае совокупного функционирования государственных и общественных ресурсов.

В частности, уголовное судопроизводство может быть эффективным в своем воспитательном воздействии на граждан лишь сочетая в себе не только правовые, но и нравственно-этические основы.

В 2013 году, В.А. Авдеев отметил, что: «увеличение показателя числа ранее судимых указывает на то, что в отношении каждого третьего лица, подвергнутого мерам уголовно-правового характера, не были реализованы соответствующие функции и достигнуты установленные законом цели» [1, с. 43]. Данное замечание, как нам кажется, свидетельствует о наличии проблемы, выражающейся в слабой интенсивности развития нравственных начал уголовного судопроизводства, что в свою очередь негативно сказывается и на эффективности применения указанных В.А. Авдеевым мер.

На сегодняшний день, проанализировав данные судебной статистики, предоставленной Судебным департаментом при Верховном Суде Российской Федерации, можно выделить, что: в 2018 году всего по составам УК осуждено 628291 лицо, из них 239339 лиц имело неснятые или непогашенные судимости на момент судебного рассмотрения по вновь совершенным преступлениям (15607 за совершение особо тяжких преступлений, 60956 за совершение тяжких преступлений, 64257 за совершение преступлений средней тяжести и 98519 за совершение преступлений небольшой тяжести); в 2019 году всего по составам УК осуждено 598214 лиц, из них 230061 лицо имело неснятые или непогашенные судимости на момент судебного рассмотрения по вновь совершенным преступлениям (14191 за совершение особо тяжких преступлений, 54517 за совершение тяжких преступлений, 59109 за совершение преступлений средней тяжести и 102244 за совершение преступлений небольшой тяжести); в 2020 году всего по составам УК осуждено 530998 лиц, из них 212051 лицо имело неснятые или непогашенные судимости на момент судебного рассмотрения по вновь совершенным преступлениям (13300 за совершение особо тяжких преступлений, 50835 за совершение тяжких преступлений, 52730 за совершение преступлений средней тяжести и 95186 за совершение преступлений небольшой тяжести) [2].
Безусловно доля осужденных в России на данный момент уменьшается, а число преступлений средней и небольшой тяжести, гораздо выше, чем число совершающихся особо тяжких и тяжких преступлений, однако указанные выше цифры едва ли можно назвать утешительными.

Отметим, что в случае если ранее судимое лицо вновь совершает умышленное преступление, можно с полной уверенностью констатировать факт не реализации воспитательной функции как наказания, так и иных мер уголовно-правового характера, что несомненно препятствует достижению целей, предусмотренных законом и подтверждает факт морально-нравственной деградации такого лица.

Несмотря на сказанное выше, отметим, что применение более сурового наказания зачастую препятствует не только восстановлению справедливости, но и исправлению лица, виновного в совершении преступления, кроме того, в ряде случаев может поспособствовать его дальнейшей десоциализации и даже в некоторых случаях подтолкнуть к совершению новых преступлений. Также стоит отметить, что не являются исключением и случаи, когда, будучи осужденным за преступление небольшой или средней тяжести, лицо впоследствии совершает тяжкое или особо тяжкое преступление. Учитывая особенности данной проблемы, ее решение видится нам в укреплении нравственных начал уголовного судопроизводства, через совершенствование механизмов применения мер уголовно правового характера, в частности института прекращения уголовного дела или уголовного преследования с назначением судебного штрафа, регламентируемого ст. 25.1 УПК РФ, который может быть применен в отношении лиц, совершивших преступления небольшой и средней тяжести.

Современная уголовно-правовая политика нашего государства, отвечая мировым тенденциям, постепенно, переориентируется на использование альтернатив уголовному наказанию, среди которых свое законное место занимает как раз институт судебного штрафа. В ч. 1 ст. 25.1 УПК РФ указано: «Суд по собственной инициативе или по результатам рассмотрения ходатайства, поданного следователем с согласия руководителя следственного органа либо дознавателем с согласия прокурора, в порядке, установленном настоящим Кодексом, в случаях, предусмотренных статьей 76.2 Уголовного кодекса Российской Федерации, вправе прекратить уголовное дело или уголовное преследование в отношении лица, подозреваемого или обвиняемого в совершении преступления небольшой или средней тяжести, если это лицо возместило ущерб или иным образом загладило причиненный преступлением вред, 
и назначить данному лицу меру уголовно-правового характера в виде судебного штрафа» [3].

Отметим, что данный процессуальный институт, близкий к зарекомендовавшему себя за долгие годы за рубежом институту трансакции, демонстрирует направленность отечественного законодателя на гуманизацию национальной уголовно-правовой политики. Учитывая в первую очередь принцип гуманизма, суду в ряде случаев следует отдавать предпочтение именно иным мерам уголовно правового характера, среди которых мы считаем наиболее приоритетной прекращение уголовного дела или уголовного преследования с назначением судебного штрафа ввиду ее ярко выраженной нравственной основы.

Считаем, что всякая деятельность, в частности деятельность, связанная с осуществлением правосудия, должна реализовываться, основываясь на нравственных и моральных принципах.

Нравственные принципы общеприняты и характерны для всех сфер общественной жизни. Наиболее распространенными из них в современном обществе являются: человечность, почтительность, разумность, мужество и честь. К моральным принципам можно отнести такие как: справедливость, терпимость, милосердие, гуманность и другие.

Назначение уголовно-процессуальной деятельности связано с охраной прав и законных интересов личности что, как нам кажется, демонстрирует ее нравственный характер. Также стоит заметить, что нравственные отношения, сопутствующие деятельности участников уголовного судопроизводства дополняют правовые отношения, нередко влияя в той или иной степени на исход дела. Из этого можно сделать вполне обоснованный вывод о том, что эффективное решение задач уголовно-процессуальной деятельности, осуществимо за счет совокупного исполнения требований не только законности, но и нравственности.

И.А. Насонова, по нашему мнению, абсолютно верно утверждает, что: «Нравственные требования в сфере уголовно-процессуальной деятельности способствуют созданию системы моральных приоритетов, которая определяет нравственную линию поведения участников процесса, выполняет воспитательную задачу» [4, с. 55].

Российские граждане, как нам кажется, имеют стойкую потребность к чести, справедливости и истине, что находит свое отражение в появляющемся недоверии к отечественному уголовному судопроизводству. Даже учитывая законность, справедливость и обоснованность решений суда, гражданам эти решения не всегда понятны, в первую очередь из-за отсутствия в них наглядности, выражающейся в отсутствии видимой опоры на моральные и нравственные человеческие ценности.

А.В. Победкин, по нашему мнению, верно подметил, что: «уголовно-процессуальный закон, который не формирует у граждан убеждения в справедливости судопроизводства, создает почву для представления о собственной второсортности, незащищенности не может воспитывать лучшие человеческие качества» [5, с. 42]. Данное утверждение несомненно свидетельствует о необходимости увеличения количества социальных проявлений в уголовном процессе.

Уголовное судопроизводство справедливо можно считать своего рода инструментом воспитания общества, в первую очередь за счет принципа публичности, выражающейся в защите членов общества от преступных проявлений. Однако, приоритет материального перед духовным, в частности в случае с применением института судебного штрафа, вызывает немало споров и дискуссий в отечественной научной среде. А.Г. Маркелов, по нашему мнению, наиболее конкретно сформулировал одну из ключевых проблем прекращения уголовного дела или уголовного преследования с назначением меры уголовно-правового характера в виде судебного штрафа, указав, что: «Состоятельная часть населения будет «уходить» от уголовной ответственности (нарушение принципа неотвратимости наказания), зная, что можно откупиться» [6, с. 108].

Указанное выше утверждение, к сожалению, отчасти является верным, учитывая, что ярко выраженную материальную составляющую института судебного штрафа в виде возмещения ущерба, заглаживания вреда иным способом и пополнение казны государства посредством уплаты определенной денежной суммы, назначенной судом лицу, виновному в совершении преступления. Нравственная основа института судебного штрафа заключается в предоставлении государством лицу, совершившему преступление (в случае соблюдения условий ст. 76.2 УК РФ), переосмыслить свое поведение и подтвердить свой статус достойного члена общества.

Текущая действительность в области уголовного судопроизводства, как нам кажется, требует усиления именно нравственной основы института судебного штрафа, сделав невозможным уход от уголовной ответственности «по-тихому», признав вину, возместив ущерб и уплатив определенную сумму в счет государства. Считаем, что эффективность данного института освобождения от уголовной ответственности может быть существенно повышена, посредством введения нового условия его применения, призванного воззвать 
к совести и социальной ответственности виновного лица.

Проанализировав положения ст. 76.2 УК РФ, содержащей основания освобождения от уголовной ответственности с назначением судебного штрафа, мы акцентировали свое внимание на заглаживании причиненного преступлением вреда иным образом [7].

А.М. Каримов указывает, что: «понятие «вред» определяет все негативные последствия совершенного преступления, умаление каких-либо благ и отражает негативные последствия совершенного преступления как имущественного, так и неимущественного характера. Оно включает в себя как имущественные, так и моральные потери, телесные травмы, не подлежащие денежному измерению» [8, с. 373]. Термин «заглаживание», по сути, означает «смягчение» или «преуменьшение» последствий совершенного преступления. Из этого следует, что заглаживание вреда - это добровольные действия виновного, направленные на уменьшение пагубных последствий совершенного им преступления.

Учитывая важнейшее обстоятельство, предполагающее наличие положительного посткриминального поведения лица, совершившего преступление, выражающегося в заглаживании вреда при освобождении от уголовной ответственности в связи с назначением судебного штрафа, не остается сомнений в наличии нравственных и гуманистических начал данного института. Однако, как нам кажется, для усиления связи государственной власти с обществом, непосредственно в рамках уголовного судопроизводства, стоит обратить внимание на форму заглаживания вреда, причиненного преступлением в виде принесения извинений.

Г.Ф. Шершеневич, как нам кажется, верно отметил, что: «Только принесение извинений будет достойной компенсацией нравственных страданий» [9, с. 402].

Форма принесения извинений обвиняемым потерпевшему, на данный момент отечественным законодателем не регламентирована, однако, по нашему мнению, стоит отметить, что извинения должны приноситься публично и на официальном уровне. Наиболее правильным способом принесения публичных извинений мы считаем совершение данного действия в рамках судебного заседания с обязательным занесением в протокол, согласно ст. 259 УПК РФ.

Как показывает практика, извинения не всегда принимаются потерпевшей стороной, однако данное обстоятельство ни в коей мере не препятствует обвиняемому их приносить, учитывая, что данные действия являются его волеизъявлением и не могут быть ему запрещены.
В тех случаях, когда извинения могут быть принесены конкретным лицам, в отношении которых было совершено преступление, вопросов обычно не возникает, чего нельзя сказать об извинениях обвиняемого приносимых правоохранительным или государственным органам.

Ф.Н. Багаутдинов считает, что: «практика принесения обвиняемым публичных извинений в адрес государственных органов, их представителей и учета таких действий судами как заглаживание вреда является необоснованной. Данным государственным органам непосредственно вред от преступных действий не был причинен, и они не уполномочены принимать такие извинения» $[10$, с. 11]. Не можем согласиться с данным мнением, учитывая наличие тесной связи государства и общества, которая помимо прочего находит свое непосредственное отражение в уголовном процессе. Считаем, что принесение извинений государственным органам через их представителей, только сильнее укрепляет эту связь, а также наглядно демонстрирует социальную направленность уголовного судопроизводства.

Отсутствие потерпевшего, также не является препятствием для публичного принесения извинений, о чем можно судить исходя из мнения Е.А. Хлебницыной, которая, как нам кажется, верно утверждает, что: «если потерпевший по уголовному делу отсутствует, заглаживание вреда и его объем могут определяться виновным, а их достаточность оценивается судьей при решении вопроса об освобождении от уголовной ответственности с назначением судебного штрафа» [11, C. 143].

Принесение публичных извинений виновным лицом, зачастую способно оказать благоприятное воздействие на потерпевшего, эмоциональное состояние которого было нарушено вследствие совершенного преступления. Данный факт, несомненно, будет являться также демонстрацией осознания виновным лицом своих действий и глубокого раскаяния в них не только лицу, потерпевшему от преступления, но и обществу. Считаем, что воспитательная функция уголовного судопроизводства, основывающаяся на его нравственных и гуманистических началах, будет усилена с помочью принесения извинений, в рамках применения к виновному лицу института судебного штрафа, которые способны пробудить в лице, совершившем преступление, чувства вины и ответственности, воззвать к его совести.

Исходя из вышесказанного считаем необходимым законодательно закрепить публичное принесение извинений виновным лицом в рамках судебного заседа- 
ния как обязательное условие прекращения уголовного дела или уголовного преследования с назначением меры уголовно-правового характера в виде судебного штрафа, дополнив часть 1 ст. 25.1 УПК РФ положением нижеследующего содержания:

«если это лицо возместило ущерб или иным образом загладило причиненный преступлением вред, а также принесло публичные извинения». Далее по тексту.
Данная мера, по нашему мнению, будет способствовать укреплению морально-нравственных ориентиров личности виновного лица, а также восстановлению социальной справедливости. Благодаря необходимости публичного принесения извинений, каждый человек, совершивший преступление будет обязан отвечать не только перед государством, но и перед обществом, интересы которого оно обязано защищать.

\section{ЛИТЕРАТУРА}

1. Авдеев В.А. Оптимизация целей наказания в контексте предупреждения преступности / В.А. Авдеев // Криминологический журнал Байкальского государственного университета экономики и права. - 2013.— № 2.— С. 43-53.

2. Данные судебной статистики // Судебный департамент при Верховном Суде Российской Федерации: [сайт]. — 2009-2021.— URL: http://www.cdep. ru/index.php?id=79 (дата обращения 18.06.2021).

3. Уголовно-процессуальный кодекс Российской Федерации от 18 декабря 2001 года № 174-Ф3 (редакция от 30 апреля 2021 года): [принят Государственной думой 22 ноября 2001 года: одобрен Советом Федерации 5 декабря 2001 года] // Консультант Плюс: правовой сайт. — 1992-2021.— URL: http://www.consultant.ru/document/cons_doc_LAW_34481/065cab20965a72aeb6a03973f7d33d6e07612798/

4. Насонова И.А. 0 роли нравственных начал в деятельности участников уголовного судопроизводства / И.А. Насонова // Судебная власть и уголовный процесс.-2015. - № 4.- С. 48-55.

5. Победкин А.В. Уголовное судопроизводство как невостребованное средство воспитания человека / А.В. Победкин // Вестник экономической безопасности. - 2019. - № 1.- С. 40-45.

6. Маркелов А.Г. Новый доказательный компромисс в уголовном процессе России: «заплати и спи спокойно» / А.Г. Маркелов // Вестник Казанского юридического института МВД России. — 2017. — № 2 (28). — С. 105-108.

7. Уголовный кодекс Российской Федерации от 13 июня 1996 года № 63-Ф3 (редакция от 11 июня 2021 года): [принят Государственной думой 24 мая 1996 года: одобрен Советом Федерации 5 июня 1996 года] // Консультант Плюс: правовой сайт. - 1992-2021.— URL: http://www.consultant.ru/ document/cons_doc_LAW_10699/52baec5d327332967e03384ce7a8befdc3d83f15/ (дата обращения 24.06.2021).

8. Каримов А.М. Терминологическая коллизия института заглаживания вреда, причиненного преступлением, в Российском законодательстве / А.М. Каримов // Вестник Казанского юридического института МВД России. — 2018. — № 3 (33). — С. 370-376.

9. Шершеневич Г.Ф. Учебник русского гражданского права: в 2 т. / Г.Ф. Шершеневич. — Москва: Консультант Плюс: Статут, 2005. — Т. 1. — 460 с.

10. Багаутдинов Ф.Н. Принесение извинений как форма заглаживания причиненного преступлением вреда при назначении судебного штрафа / Ф.Н. Багаутдинов // Вестник Самарского юридического института. — 2019.— № 3 (34). - C. 9-13.

11. Хлебницына Е.А. Возмещение ущерба или заглаживание причиненного преступлением вреда иным образом как условие освобождения от уголовной ответственности с назначением судебного штрафа / Е.А. Хлебницына // Вестник экономической безопасности._ 2018. — № 2. — C. 139-144.

(с Соловьев Александр Георгиевич ( solovevag2507@gmail.com ). 